optic and otic region. This change of the grey matter occurs also in the brain tissue belonging to the donor which has been involved in the transplantation either in the anterior, middle, or posterior brain. In any event, the shifting and increasing of cells in the grey matter are always quantitatively greater with a double fused nerve. Therefore the affinity between nerve centres and sense organs is shown by a reaction of growth (cell division) which occurs in the region corresponding to the supernumerary sense organ. The latter, for that reason, must have a very clear influence on the development of nervous centres.

These results are in harmony with the recent investigations of Harrison ${ }^{8}$ concerning development and growth of heteroplastically transplanted eyes.

Department of Zoology,

University of Rome, Italy.

P. Pasquini, Boll. Ist. Zool. Roma, vol, 5 ; 1927.

2 S. R. Detwiler, Arch. für Entwicklungsmech., Bd. $116 ; 1929$.

a R. M. May and S. R. Detwiler, Jour. Exp. Zool., vol. 43 ; 1925.

R. M. May and S. R. Detwiler, Jour. Exp.

G. M. May, Arch. de Biol, vol. 37 ; 1927. 6 H. S. Burr, Anat. Rec., vol. 25, 1923

1924; Jour. Exp. Zool., vol. 55, 1930.

7 P. Pasquini, Rend. $R$. Acc. Naz. Lincei, 10, serie 6, 2 sem., 1929.

\&. G. Harrison, Arch. für Entwicklungsmech., Bd. 120 ; 1929.

\section{Periodic Fluctuations in a Vertical Temperature} Gradient.

THE accompanying diagram (Fig. 1) suggests a striking example of wave motion in the vertical temperature gradient at St. Hubert Airport, near Montreal, during a large inversion of lapse rate in the
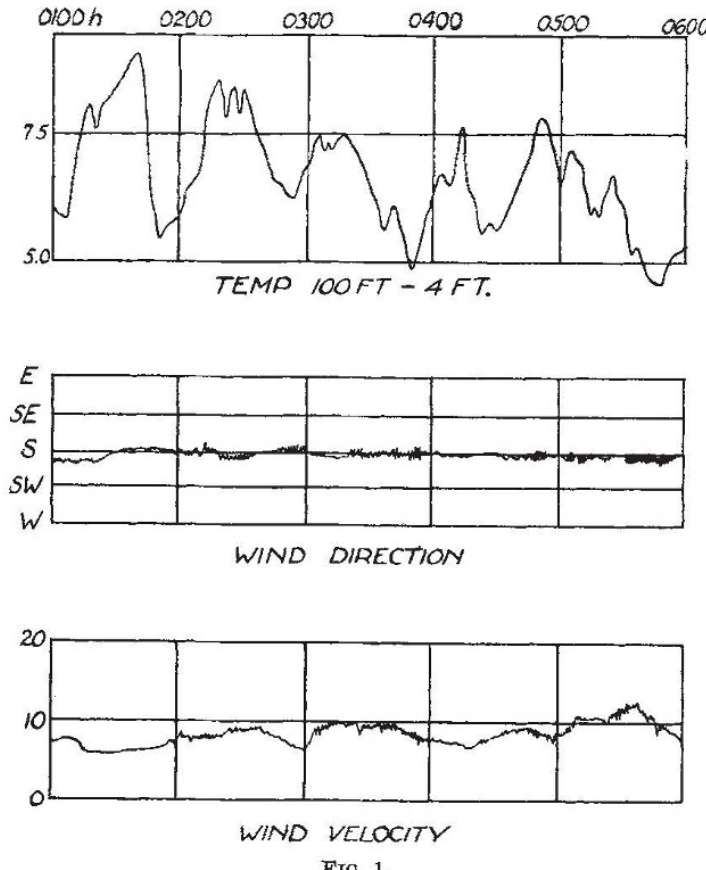

FIG. 1.

early morning of Oct. 12, 1930. The upper curve shows the temperature at 100 feet above the ground minus that at 4 feet, in degrees Fahrenheit. The lower curves show the velocity and direction of the wind at 60 feet.

Five complete waves occur in the vertical gradient between 0105 hours and 0520 hours, with an average period of about 50 minutes. The gradient in question was measured by platinum resistance thermometers continuously ventilated by a fan.

The barometer was very steady, and the wind unusually so. At this time, the station was about 300 miles from the centre of a large, slow-moving anticyclone about 1500 miles in diameter. Very light winds had prevailed for three days, and unseasonably high daytime temperatures. There is no information about eloud at this station at night, but the skies were cloudless for two days before and the day after, which renders it likely that the night was clear. The country to the south of St. Hubert (from which direction the wind was blowing) is very flat for some miles.

During more or less stationary anticyclonic conditions, fluctuations of the same general magnitude often occur in the early hours of the morning ; but in this example the periodicity is especially apparent.

W. E. Knowles Middleton.

Meteorological Office,

315 Bloor Street, West,

Toronto (5), Dec. 15.

\section{The Value of $M / m$.}

Prof. H. S. Allen has directed my attention to the short account in NATURE of Dec. 13, p. 942, of a recent paper by Sir Arthur Eddington, in which Sir Arthur suggests on theoretical grounds that $M / m=(136)^{2} / 10$ $=1849 \cdot 6$. Prof. Allen in 1915 suggested $^{1}$ that a relationship of this type might be true.

Assuming that $M_{B} / m=1850 \cdot 6$, and taking the values of the Faraday constant and atomic weight of hydrogen as given by Birge, ${ }^{2} \mathrm{I}$ deduce

$$
e / m=\left(1 \cdot 7719 \pm 0 \cdot 0001_{3}\right) \times 10^{7} .
$$

Now this is not only higher than I estimate, ${ }^{3}$

$$
\left.\begin{array}{l}
1 \cdot 7688_{2} \pm 0 \cdot 0006_{3} \\
1 \cdot 767_{7} \pm 0 \cdot 001
\end{array}\right\} \times 10^{7}
$$

but also is higher than the values given by Birge, higher than two recent determinations, ${ }^{5}$ and higher than all the final values tabulated in the "Handbuch der Physik" (22, p. 81) and in J. J. and G.P. Thomson's "Conduction of Electricity through Gasses" (1,p. 264) -with the exception of the one higher determination of Classen. This seems to me sufficient evidence to show that $M_{P} / m$ cannot be exactly $1849 \cdot 6$. There is, however, more evidence to this effect.

Using the estimate $e / m=\left(1 \cdot 7719 \pm 0 \cdot 0001_{3}\right) \times 10^{7}$, together with Rydberg's formula and Eddington's equation $h c / 2 \pi e^{2}=137$ (experimental evidence for which I explained in my December paper), I deduce :

$$
\begin{aligned}
& e=\left(4.771_{6} \pm 0.0004\right) \times 10^{-10} \\
& h=\left(6.537_{3} \pm 0.0009\right) \times 10^{-27}
\end{aligned}
$$

(for the subsidiary data I have used Birge's values). These estimates of $e$ and $h$ may at first seem acceptable enough : but when they are compared with the determinations of $h$ by five other methods as given by Birge, ${ }^{6}$ using the graphical method given in my paper, it is found that all five deviate from the present estimates in the same sense. As there is only a probability of 1/16 of the five being all in error in the same sense, I can only conclude that this is more evidence against the equation $M / m=1849 \cdot 6$.

Department of Physics,

$$
\text { W. N. BOND. }
$$

University of Reading,

$$
\text { Jan. } 3 .
$$

1 Proc. Phys. Soc., 27, p. 430

2 Phys. Rev. Supplement, vol. 1, No, 1, pp. 1-73.

s Phil. Mag., Dec. 1930.

Loc. cit

Phys. Rev. 1930

Loc. cit. p. 57.

No. 3196, VoL. 127] 